\title{
Emergence of Geotourism Activity at João Pessoa Municipality and South Coast of Paraíba (Ne Brazil)
}

\author{
Luciano Schaefer Pereira ${ }^{1, a^{*}}$, Lúcio Sobral da Cunha ${ }^{2, b}$, \\ Marcos Antonio L. do Nascimento ${ }^{3, c}$ \\ ${ }^{1}$ Department of Geography, Faculty of Humanities, University of Coimbra, S. Jerónimo College,
$3004-530$ Coimbra \\ ${ }^{2}$ Department of Geography, Faculty of Humanities, University of Coimbra, Colégio de S. Jerónimo, \\ 3004-530 Coimbra \\ ${ }^{3}$ Department of Geology, University of Rio Grande do Norte, Natal, Brazil, Avenida Salgado Filho, \\ S/N, Bairro Lagoa Nova, Campus Universitário, Postal Code 1678 \\ alschaefer2@gmail.com, bluciogeo@fl.uc.pt, 'cmarcos@geologia.ufrn.br
} Keywords: João Pessoa, South Coast, Geoheritage, Geotourism, Geo-Routes, Geotouristic
Interess Local.

\begin{abstract}
The municipality of João Pessoa and the south coast of Paraíba, admittedly, is a tourist destination for 3S (sand, sea and sun) market. It has a geomorphological, geological, pedological and hidrological heritage still little studied for geotourism purposes, whose contribution of this paper is to encourage discussions about this niche, yet incomplete, tourism, notably in the Paraíba State. The preliminary aim is to suggest potential sites that reflect the geodiversity of the area, with the aim of mapping the future of it, resulting the elaboration of a Geoturistic Guide of this coastal area. The geosedimentary history of the urban site of area dates back to the late moments of the separation of the supercontinent Pangea, forming the Paraiba basin. The urban development of geotourism in João Pessoa and surrondings is a dynamic way to publicize their geoheritage to a greater number of people, whether tourists or not, for it geoconservation. This practice still keeps its infancy, and the inventory of this geoheritage, as well as biotic and geomorphological heritage, with the intention of spreading the geosciences, it is necessary and is of huge importance to urban planning and management.
\end{abstract}

\section{Introduction}

Tourism activity has a long history, but it has never been as deeply discussed as it's being now, particularly in the aspects that associate cultural with natural features [12]. Ecotourism, adventure tourism, rural tourism and geotourism are some examples of the touristic aspects that renewed its activity. With these activities, capital has increased its circulation, increasing income, improving the quality of life of those involved, and - when performed in a sustainable way extending the lifetime of biotic environment, and aiding the preservation of the abiotic environment. This growth has created new territorialities in space, and any element of this space that can be inserted into the tourism dynamics is welcome.

Geotourism is a new activity aiming to assess, promote and disclosure the geological and geomorphological heritage, including forms and processes [6], adding the abiotic environment to flora and fauna elements and using geoheritage in a sustainable manner. The pioneering definition involving the term 'geotourism' was proposed by Hose [8] like 'the provision of interpretive and service facilites to enable tourists to acquire knowledge and understanding of the geology and geomorphology of a site (including its contribution to the development of the Earth Sciences) beyond the level of mere aesthetic appreciation".

Brilha [4] considers the geoheritage synonymous of geological heritage, and his definition is "geosites set of a a local, geographically delimited, where there are geodiversity elements with unique values from a scientific point of view, educational, cultural or tourist. It consists of all non- 
renewable natural resources, whether geological or geomorphological formations, landscapes, mineralogical and paleontological outcrops".

However, in the scientific community, geographers and geologists are not unanimous in the conceptualization and differentiation than are geological and geomorphological formations. Most geologists refers to part of the abiotic environment as can constitute geological heritage, while the geographical class differs geology and geomorphology. The prefix 'Geo' means 'Earth' and not 'Geological'. In this paper, the term 'geoheritage', which was disseminated widely in scientific circles as Geological Heritage, is reset to 'Geopatrimônio', encompassing all elements of the abiotic environment that have heritage value, such as soil, the relief features (geomorphological), the geological features (rocks, minerals, fossils and stratigraphy) and water resources, subsurface or not (hydrological), similar to what came to be proposed by Rodrigues and Fonseca [23], i.e. both nonrenewable resources as well as renewable.

The urban geotourism, today, manifests itself as an important segment or area within the geotourism. But, knowing and mapping the cultural heritage, which include churches, houses, monuments, paved roads, etc, describing its architecture and history, identifying belonging lithologies, characterizing them petrographically and, if possible, identifying their origin, we can propose measures to encourage and ensure their geoconservation and disclose their geodiversity, which Rodrigues [24] considers a broad version of this concept, as opposed to the narrow sense, which would include only the natural aspects, executed mainly in the countryside.

In October 2007, Montreal (Canada) became the first city in the world to sign the Geotourism Charter of the National Geographic Center for Sustainable Destinations (Geotourism Charter of National Geographic's Center for Sustainable Destinations- CSD). This letter includes 13 basic principles, namely: integrity of place; international codes; market selectivity; market diversity; tourist satisfaction; community involvement; community benefit; protection and enhancement of destination appeal; land use; conservation of resources; planning; interactive interpretation; and evaluation [5]. Several global meetings have taken place to discuss the geotourism. The first major meeting was the Inaugural Global Geotourism Conference, held in Perth, Australia (2008), followed by the World Heritage and Geotourism Conference in Pretoria, South Africa (2009). To these pioneering conferences, several other succeeded and so relevant topic discussions have been strengthened worldwide.

In this article, Geoheritage is referred to the set of values that represent the geodiversity of the territory, composed of abiotic natural elements existing on the surface (submerged or surfaced) that must be preserved because of its heritage value. Thus, Geoheritage is considered as including the Geological Heritage, the Geomorphological Heritage, the Hydrological Heritage and the Pedological Heritage.

In this context, geotourism arises by inserting geodiversity elements on tourism, therefore generating different physical spaces of appreciation, or using old spaces but viewed under a new light. Rock and their minerals, fossils, relief, soil, water, among others, are some examples of the elements that increased this tourist activity. This geoheritage can be described and interpretated in sites, provided there are important aspects to promote its interpretation, and always aiming to benefit the local community, and introducing environmental awareness to the population involved.

In Brazil, geoturist activity rose at the beginning of this millennium, initially influenced by the project entitled 'Geological Paths', developed by the Geological Survey of Rio de Janeiro since 2001 [14] and subsequently by the 'Geological and Paleontological Sites of Paraná Program', by the Geological Survey of Paraná / MINEROPAR [22]. These projects intend to enhance the geoheritage, which is a source of scientific and educational knowledge. Sustainable geotourism, whether urban, coastal and rural, should aim at geoconservation of the abiotic and cultural memories of these sites, developing a greater awareness and understanding of the importance of geotourism for the local economy, community and the environment itself.

João Pessoa, capital of Paraíba State, Northeastern Brazil, has a coastline that borders the municipalities of Cabedelo, to the north, and Conde, to the south, and all of them are places of intense tourist attraction for its beautiful scenarios, including paradise beaches and cliffs. This work 
presents the geotouristic potential of the coast of João Pessoa and south coast, between the mouth of the Rio Paraíba in Cabedelo, until Abiai Depression, at the municipality of Pitimbu (Fig. 1), through the identification and inventory of these sites of geotouristc interest. This wealth of information will be the basis for the writing of an Urban Geotouristic Guide, in order to promote the popularization and understanding of geosciences and serve as a record of geoheritage in the urban site and region. The result of these studies will not only help in scaling the regional tourism industry, adding value to tourism, às well will disclose the geodiversity of the area, aiming at its geoconservation.

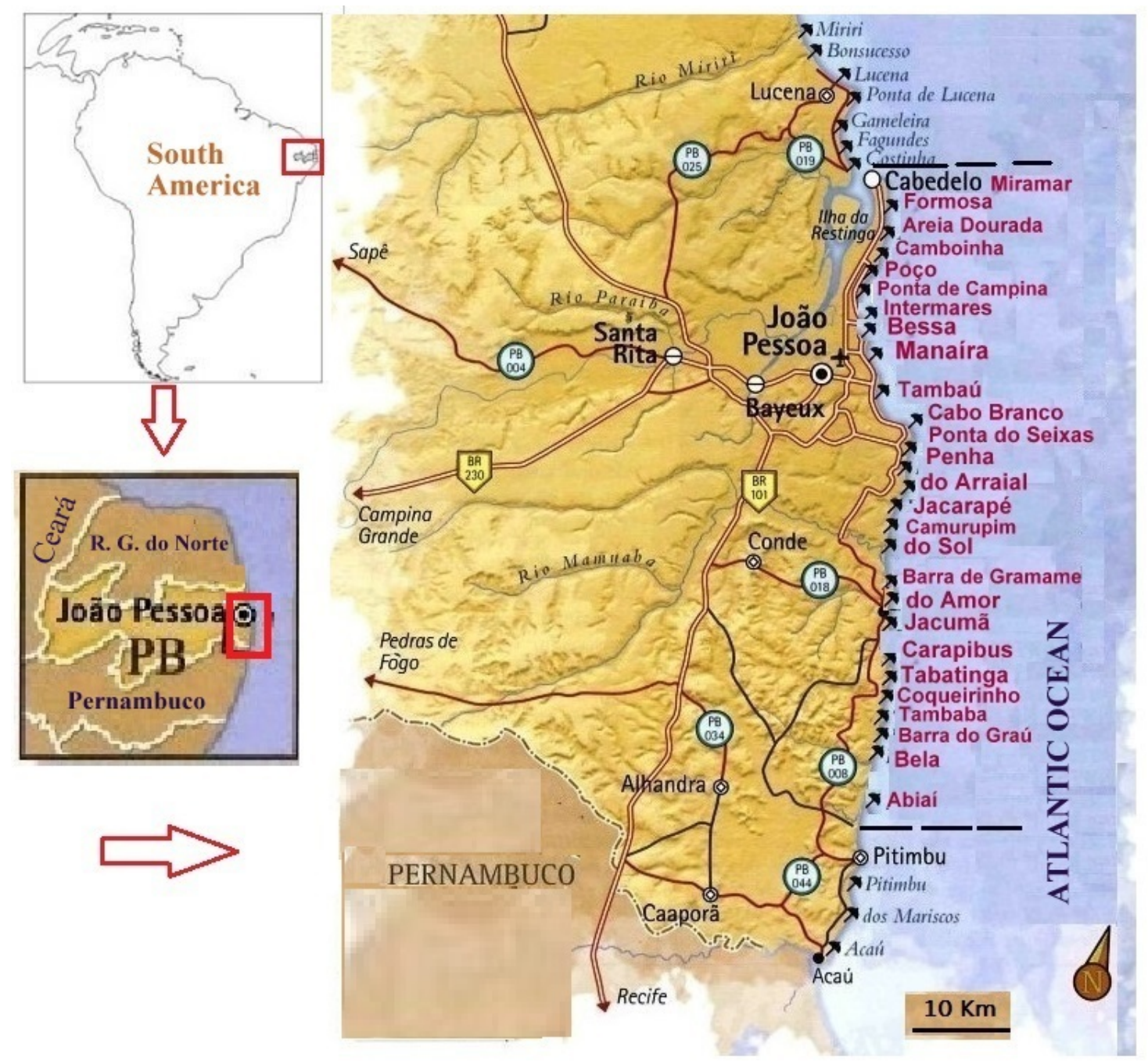

Figure 1. Location of the study area (between the dashed lines). Source: the authors.

This geotouristic guide will enable proposing guided urban geotrails, preparation of brochures and interpretative panels for sites of major geotouristic interest. The geotourist activity involves the public and private sectors, universities, among others, in a broad spectrum of structural actions, which will include transportation, access, accommodation and services, thus serving to generate employment and income, and contributing to the quality of life of local communities, as will be seen later. Visitors should receive high quality information about geodiversity and history of the visited sites, and should be aware, as well as the local population, that they must keep the quality of this geoheritage for the generations to come.

\section{Methodology}

The proposed work involves four sequential phases, currently in development. They are:

1. Bibliography: at this stage, the scientific production involving historical, geomorphological and geological studies, including tectonics, about the southern coast of the state of Paraiba, was 
analyzed to increase the knowledge involving the genesis of the landscape, as well as the understanding of cultural and functional value of geodiversity, when related to the settlement and urban development in the region;

2. Fieldwork: at this stage, sites of geotouristic interest were visited, in order to identify geotouristic values, which helped in the selection of those to be inserted in the later stages of the project. Therefore, topographic maps were used, scale 1:25,000, aerial photographs in scale 1:8,000 and satellite images, as well as images ASTER / TERRA, VNIR bands, with a spatial resolution of $15 \mathrm{~m}$.

3. Inventory (qualitative evaluation): in this step, geoheritage segment were identified (as geological, geomorphological, pedological or hydrological heritage), considering the scale used, from outcrop (meters) to landscape $(\mathrm{km})$. Thus, a database was created with heritage elements that have geotouristic use value, according to their logistic facilities, scenic beauty, cultural value, among others, by filling out assessment files that include the absolute and relative location, photography, access, description of the physical characteristics, etc.

This research, in progess, will culminate with the elaboration of a Geotouristic Guide of João Pessoa and South Coast of Paraíba, which will enable the proposition of guided geotrails. Furthermore, it suggests the placement of richly illustrated panels, bearing information about their origin, in those places of greatest geotouristic value with tectonic, petrographical, geomorphological, pedological and hidrological information, among others. Thus, the sites were valued and identified by their cultural, ecologic, scientific and, mainly, aesthetic values. The Geotouristic Guide they will provide them public exposure, as well publicize the local geodiversity and, indirectly, the geosciences.

\section{Geological and Geomorphological Context of the Study Area}

João Pessoa and the south coast are located in the topographic chart of João Pessoa (SB-25YC-3), scale 1:100,000, prepared by the Army Ministry. The geology of the research area is associated with the Paraíba sedimentary basin. Such sediments were deposited as the South American continent drifted away from the African continent [7], over a crystalline basement deformed by shear zones [10]. This basin can be subdivided into three sub-basins: Olinda, Alhandra and Miriri sub-basins. The study area is part of the Alhandra sub-basin, bordered to the north by the Itabaiana fault and to the south by the Goiana fault.

The sedimentary deposit events of the Paraíba Basin are dated from the late Turonian stage, when the lands both to the North and to the South of the Pernambuco Shear Zone were reactivated [21], as the South American continent moved away from Africa, starting the land subsidence of the Paraíba Basin, which occurred later than in the basins to the north and to the south, Potiguar and Pernambuco, respectively, which were already receiving sedimentary deposits earlier, starting in the Barremian/Aptian stages [21]. This clastic-carbonate package belonging to the Paraíba Group is represented by sandstones and conglomerates of the Beberibe Formation and the limestone of the Itamaracá Formation, at the base; by limestones of the Maria Farinha and Gramame Formation at the top, covered by Plio-Pleistocene poorly-sorted sediments of the Barreiras Formation and the post-Barreiras sediments, i.e., of Quaternary age (marine terraces, fluviolagoon deposits, mangrove, wind sands, coral reefs, beach rocks, all with marine-transitional origin, and alluvial fan, fluvial deposits, eluvio-colluvional and colluvional covers of continental origin).

From the Pliocene, as a result of the establishment of a stress field in the South American plate, with compression oriented E-W and N-S extension, a series of faults that reached the overlapping sediments were reactivated, having a crucial role in coastal morphology and tracing of the hydrographic network [2], as discussed below.

This area belongs to the geomorphologic unit of Plains and Coastal Tablelands, according to Ross [25], having direct relation with ancient tectonic movements, generated during the drifting apart of the South American and African plates [1], added to Cenozoic tectonic events [2].

Three sub-units can be identified in the urban site of João Pessoa and the south coast: the coastal lowland (coastal plain), the low coastal upland ('Coastal Tablelands') and the floodplains, 
which can be further sub-divided into fluvial and river-marine floodplains [24]. The top of the tablelands is linked to the plains by relatively steep slopes, where outcrops of limestones from the Gramame Formation appear in abundance, especially those faced to the Paraíba River, along a north-southwest axis.

The coastal lowlands are in direct contact with the sea, have altitudes between 0 and $10 \mathrm{~m}$, in which quaternary sedimentation of river, marine and river-marine origin filled the coastal plain, resulting in numerous geomorphological features that can be considered potential geomorfosites for their scenic beauty and/or relevant geological/geomorphological history. On the margin of the Rio Paraiba, floodplains occur on higher altitudes, where the presence of mangroves, as far way as $12 \mathrm{~km}$ from the coastline indicates their ecological importance. In the northern portion of the study area, the Cabedelo sand strip ('Restinga de Cabedelo') separates the Paraíba River from the Atlantic Ocean.

The low coastal uplands, also known as 'Coastal Tablelands', correspond to a higher, gently sloping portion of the land, with flat top, generally inclined to the east, result from the action of exogenous agents that carved the Barreiras Formation, including marine abrasion on cliffs, another outcrop form of this formation on the coast, in its eastern portion. Most of the urban site of João Pessoa sits on this geomorphological unit. According to Brito Neves et al. [3] and Rossetti et al. [27], these low plateaux are the results of large arching and a succession of steeped pediplains to inland, subordinated to paleoclimate, whose graben- horst type structure controlled its morphology.

Reactivation of basement shear zones with E- W and NE- SW direction, from the Early Cretaceous [16], reached the sediments of the Barreiras Formation, forming fault scarps that are capped by alluvial terraces, sandstone dunes, debris slopes, soil and vegetation, and which serve as bounds for the river valleys, while the upraised portions were dissected [13]. Thus, the altimetric quotas of the urban compartment of tablelands show uplifted portions (west, whose elevations reach $70 \mathrm{~m}$ ) and lowered portions (between Mumbaba River and Sanhauá River, a tributary of the Rio Paraiba, where altitudes do not exceed $40 \mathrm{~m}$ ), rising again (in the upper course of the Rio Cuiá), decreasing toward the east, and denoting the structural behavior of the graben-horst type, bounded by normal faults [2].

Away from the urban area grew the sugar production in the presence of fertile black clay soil, named 'massapê', extending away dozens of miles from shoreline. The limit of the coastal plain can be viewed along the San José Comunity, a district with serious infrastructural problems, which sat at the feet of a dead cliff, along the lower course of the Rio Jaguaribe and through a wide range of inactive cliffs, and further south where, on the other hand, the Altiplano Cabo Branco District formed, with a concentration of high-income population.

\section{Presenting the Geoheritage of the Area}

The municipality of João Pessoa is the capital of the state of Paraíba, the easternmost state of Brazil. Indeed, João Pessoa is known worldwide as the 'eastern extreme of the Americas', which already grants it a touristic potential, especially in the geomorphological aspect. Its geographical coordinates are $7^{\circ} 7^{\prime} \mathrm{S}$ and $34^{\circ} 53^{\prime} \mathrm{W}$, and the proximity to the equator gives you plenty of sunshine and high temperatures throughout the year. It has an area of $211.5 \mathrm{~km}^{2}$ and a population of 723.515 inhabitants [9], resulting in a demographic density of 3421 inhabitants $/ \mathrm{km}^{2}$, the highest in the state.

The municipality coast and its southern coast pursue numerous places of geotouristic interest, considering their aesthetic value, mainly [17-20]. One of the most interesting geomorphological features, which are distributed throughout the Paraíba coast, are the cliffs, which represent the final portion of the low coastal uplands on its eastern face, in contact with the beach, result of uplifted horsts by normal faulting type. The most famous one is the 'Cabo Branco Cliff', about 40 meters high, with its lighthouse demarcation of 'most eastern point of the Americas' (Fig. 2). In fact, besides a beautiful view of the city from the belvedere on top of this cliff, one can see, from it, the Ponta do Seixas, a sandy strand entering the ocean in Praia do Seixas, south of the cliff, which is, in reality, the extreme easterly point. Recently, in 2008, near the Cabo Branco lighthouse, a center for 
science, culture and arts Science Station was built, bearing precisely the name Science Station. The design, signed by renowned architect Oscar Niemeyer, was a reason for intense controversy for environmental problems, due to its proximity to the cliff, which suffers constant marine abrasion. In the beginning of 2015, part of the cliff collapsed.

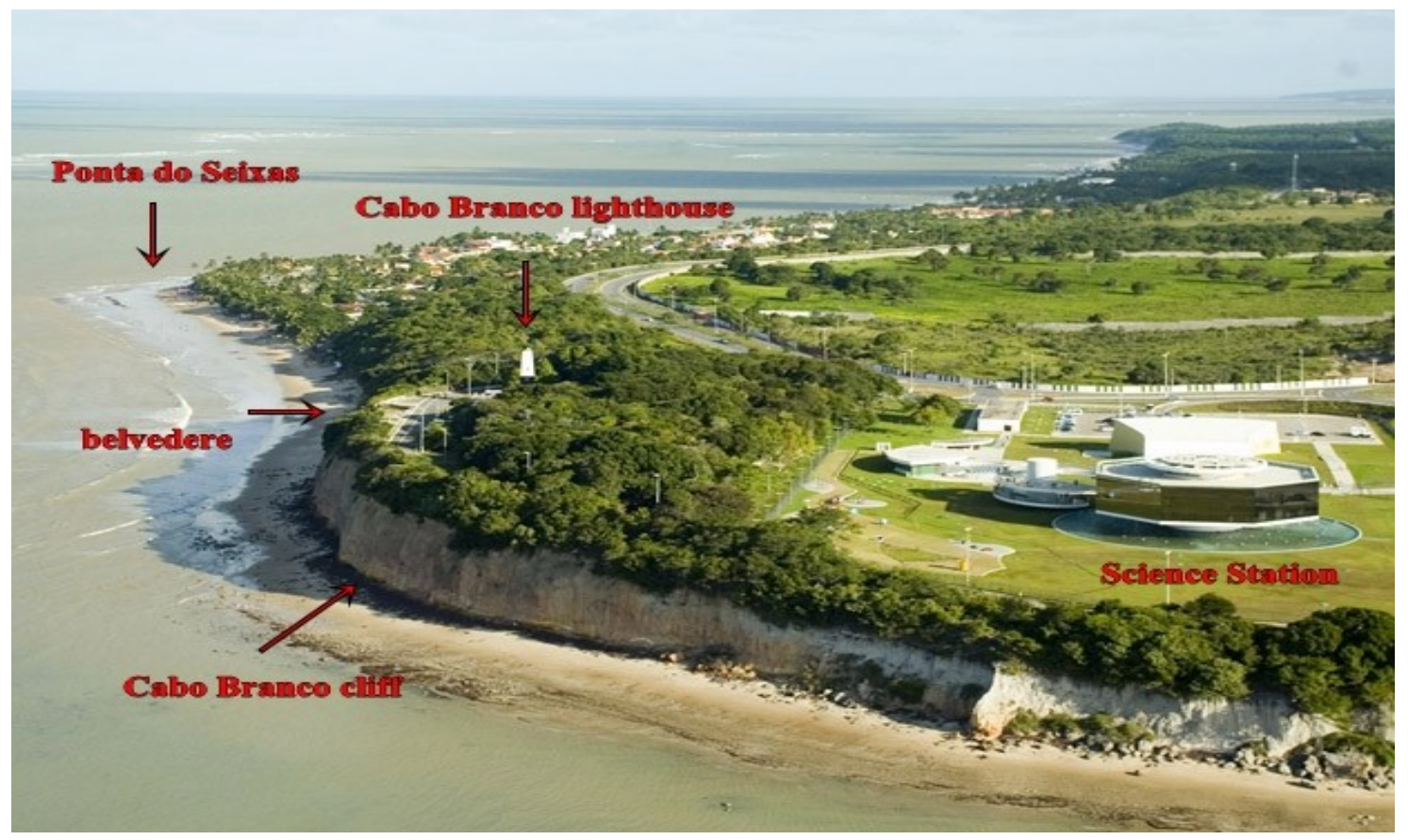

Figure 2. Aerial view of Cabo Branco Lighthouse Area, with Ponta do Seixas in the background and the Science Station in the foreground (Photo: Felipe Gesteira).

Other places of geotouristic interest based on geoheritage that were previously cited are:

- Picãozinho (Fig. 3b): one of the numerous clusters of algalic-coraligeous reefs, which are tangential to the coast and are visited daily by hundreds of tourists. They settled and grew on banks of submerged sandstones [11];

- Love Rock (Fig. 3c): one of the rare outcrop of Maria Farinha formation limestone on the south coast of Paraíba, on Jacumã beach, municipality of Conde (see Fig. 1 for localization), heartshaped, modeled by marine abrasion. The popular saying "If you pass under it, you won't be single for much longer," denotes the cultural value of this element of geodiversity;

- Cabedelo Sand Strip (Fig. 3d): representation of holocene marine terraces (Fig. 3), which have accumulated in the last marine transgression, when the sea was $5 \mathrm{~m}$ asl, 5100 years ago [28]. In modern times these terraces along the coast have been intensely occupied forming, for example, higher standart coastal neighborhoods in João Pessoa, as Bessa, Manaíra, Tambaú and Cabo Branco;

- Paraíba River Estuary (Fig. 3d): beyond its historical significance, serving as the axis for penetration and conquer of the Parahyba Real Captaincy in the late sixteenth century, and its economic importance, whose marshes and fertile soil enabled the expansion of sugarcane cultures, the first economic cycle of the colonial period, it has a geomorphological importance, representing an area of alluvial deposits in river-marine plain, whose back-and-forth of tides and deposit of clay sediments led to the consolidation of large and dense mangroves, real ecological nurseries, which also denotes its environmental importance. The hydrographic network of the coast of Paraíba is controlled by a system of NW-NE faults;

- Pleistocene marine terraces (Fig. 3e): outcrop mainly in Tabatinga beach (see Fig. 1 for localization), representing beach paleolines from 120000 years ago, when the sea level was 8 to $10 \mathrm{~m}$ asl, named Cananeia Transgression [28] or Penultimate Transgression [15], may or may not sustain paleodunes.

- Canyon of Coqueirinho (Fig. 3f): actually, they are huge ravines, named 'voçorocas', result of the action of rain water that carved the tablelands. 
Many of these sites are currently visited by various tour packages, but without a connection, systematization or even an interpretation that properly exploring their geoheritage importance. For example, every day, dozens of buggies depart for the south coast taking eager tourists for landscape appreciation, but at the return ride, eight hours later, with the mind and camera full of gorgeous images, they do not have the scientific understanding of how this landscape connects to the Earth's formation. With this, one realizes the importance of mapping the sites of the area that, when inserted into a geotouristic route designed to be covered in one or two days - a weekend, for example, result in the disclosure of this basin's geodiversity and geosciences as a whole, adding value to tourism, generating direct and indirect jobs, boosting the economy and promoting other positive consequences, without forgetting that, in the end, the sites' geoconservation must be the main focus.
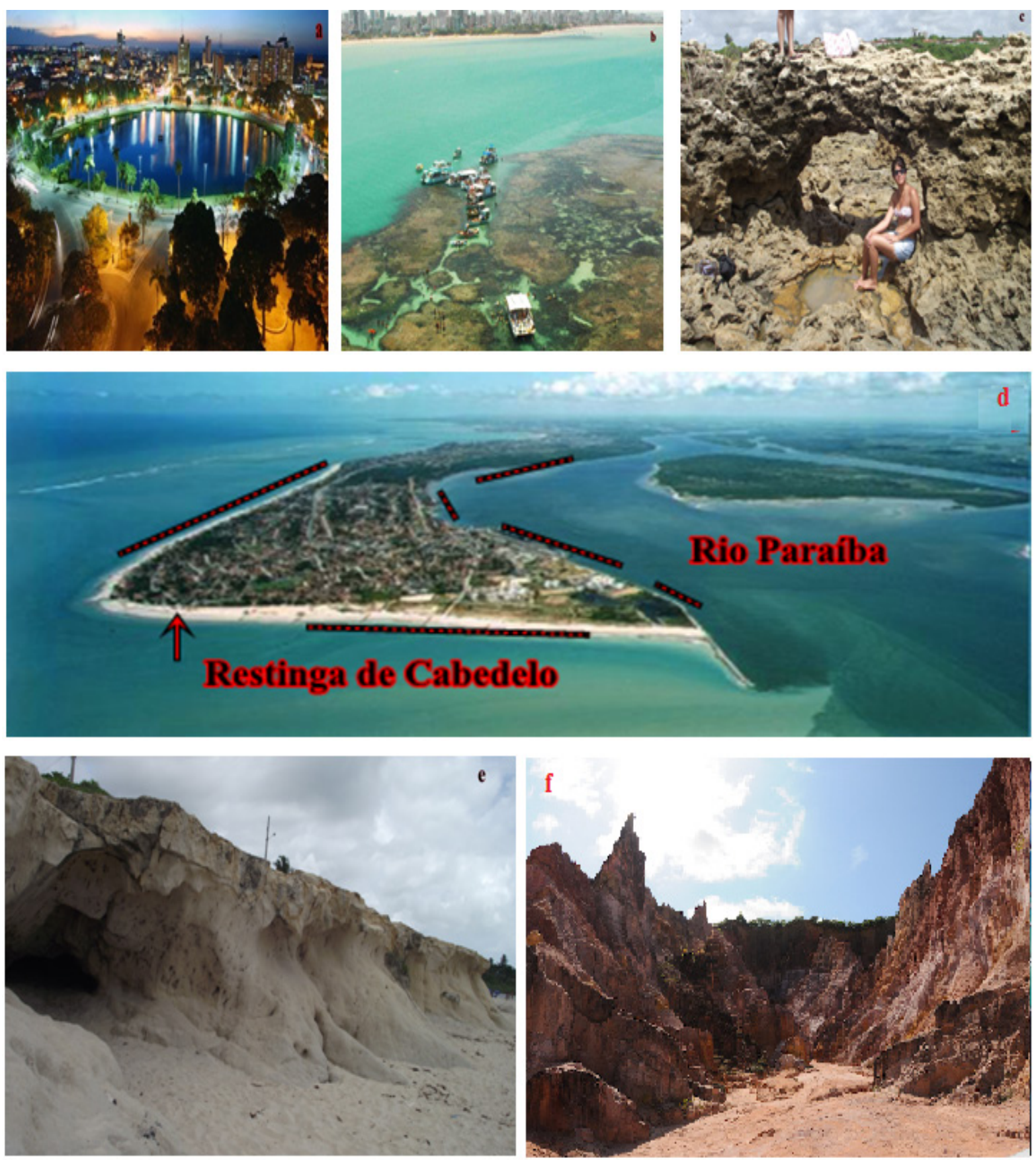

Figure 3. Aerial and surface photos of some sites of geotouristic interest: a- Lagoa dos Irerês (Photo: Guia Mais); b- Picãozinho (Photo: Brasilvip); c- Love Rock (Photo: the authors); dCabedelo Sand Strip and estuary of Paraíba River (Photo: Newsea); e- Pleistocene marine terrace (Photo: the authors); f- Canyon of Coqueirinho (Foto: SPU). 
Thus, if the role of geotourism is promoting geodiversity and its geoheritage through sites of geotouristic value, it is necessary to implement projects with scientific, educational and interpretive purposes to properly promote tourism in the area. The alliance between public-private partners is necessary in order to minimize conflicts, solve problems and deploy processes that enable the insertion of geotourist activity in the study area and the popularization of the term. Although this is not the scope of this project, it is suggested that in order to maximize the effectiveness of such a process, common goals be agreed upon and the respective shares of responsability of the government and academia be fulfilled through a collaborative alliance, thus resulting in legitimate policy decisions. These goals are:

i) conscientization of the local population - from the people who live or work near the inventoried places to students and teachers at all levels, managers, community leaders, local businesses, among others, all must be aware of the importance of the inclusion of this activity in their daily life;

ii) training and education of hand labor that will work directly with geotouristic activities. In this case, it is proposed that all those interested in this activity should be properly registered, for later specialized training through short courses in related agencies such as the National Service for Commercial Education (SENAC) and Brazilian Service to Support Micro and Small Enterprises (SEBRAE), for example;

iii) adequacy of tourism infrastructure, either interpretive or as transport infrastrucuture. In the case of geointerpretation, it is crucial to distribute maps, pamphlets, folders, brochures, etc., to tourist agencies and the installation of panels and banners on places that are part of geotouristic route. In the long run, audiovisual resources, interpretive programs, museums and other entities can be implemented in areas where geotourism is present. In this context, it's important to pre-define the rules for transport to and enjoyment of certain isolated places, such as mangrove forests, sandbanks and reefs, for example, to minimize the degradation of the natural environment.

It is the role of academia to provide favorable means for the geotourist activity to develop, the mapping of geoheritage of the area, with its inventory and semiquantitative evaluation, and elaboration of the Geotouristic Guide, so that geointerpretation, an essential component of geotourism, can be prepared and used by planners.

\section{Conclusions}

Geotourism is an emerging and still underdeveloped face of tourism, mainly in Brazil, and mapping the geoheritage of João Pessoa and south coast of Paraiba remains lacunar. The present paper aims to make an initial public exposure of this geoheritage, hoping to foster subsequent mapping of interesting geotouristic sites, in order to insert them in urban geotouristic routes. João Pessoa is a known tourist destination in Brazil, from the sun and sea tourism's point of view. It is pertinent, therefore, include the geological, geomorphological, hydrological and pedological heritage to tourism in João Pessoa, to provide another motivation to the interest of tourists.

The production of this information, brought to a wide range of researchers, scientists, students, tourists, among others, is important for the construction of an urban culture that is able to understand that the city we live in is much more complex than that of our ancestors, and that the natural elements have an important role in consolidating this achievement. It should be noted that the practice of urban geotourism, unlike that held in Geoparks or in rural areas, leads to a much higher pressure on geodiversity elements, thus increasing the vulnerability of these sites. Furthermore, those involved in touristic activities in that area have no geotouristic profile, therefore increasing threats to geodiversity.

The present work aimed to analyze the geotouristic potential of the coast of João Pessoa and the south coast, between the mouth of the Paraíba River, in Cabedelo, and Abiaí Beach, municipality of Pitimbu, through the identification and inventory of geoheritage, information that serve as the basis for the creation of an Urban and Coastal Geotourism Guide, with the purpose of promoting the popularization and understanding of Geosciences and serves as a record of geoheritage in the urban site and region. The result of these studies not only contributed to the 
increase of the regional tourist activity, adding value to the tourism, but divulgs the geodiversity of the area, aiming its geoconservation.

Further studies of this heritage shoud be carried out by experts and researchers, whose primary objective is to mobilize the local community, students, tourists, and others to manage and preserve it, by the use of embryo geoconservacionist practices, in order to publicize the geodiversity of the municipality, as well as the geosciences, and preserve its geodiversity. This work is only the first step towards interdisciplinary studies of the Paraíba coast, as seen from the perspective of tourism. A lot can be done to protect this geoheritage. Living in it in a sustainable way is a difficult but possible goal.

\section{Conflict of Interest}

The authors declare that there is no conflict of interest.

\section{Acknowledgments}

This research was supported by the Coordination for the Improvement of Higher Education Personnel (CAPES Foundation - Process \# 11988 - 13/4), from which one of the authors is a fellow of full doctorate in Physical Geography from the University of Coimbra, Portugal; the reviewers for significant improvements of the first submitted version; and to Virgínio Mantesso- Neto for colaboration in text translation.

\section{References}

[1] H.E. Asmus, Controle estrutural da deposição mesozóica nas bacias da margem continental brasileira, Revista Brasileira de Geociências. 5(3) (1975) 160-175.

[2] F.H.R. Bezerra et al., Pliocene- Quaternary fault control of sedimentation and coastal plain morphology in NE Brazil, Journal South American Earth Science. 14(1) (2001) 61-75.

[3] B.B. Brito Neves, C. Ricomini, T.M.G. Fernandes, O sistema tafrogênico terciário do saliente oriental nordestino na Paraíba: um legado proterozóico, Revista Brasileira de Geociências. 34(1) (2004) 127-134.

[4] J. Brilha, Património Geológico e Geoconservação, a conservação da natureza na sua vertente geológica, Braga, Palimage Editores, 2005.

[5] A. Cote, M.C. Joly, A. Verner, Urban geotourism: the case of Montreal, Téoros, Revue de Recherche em Tourism. 28(2) (2009) 97-99.

[6] R.K. Dowling, Geotourism's global growth, Geoheritage. 3(1) (2011) 1-13.

[7] J.B. L.Françolin, P. Szatmari, Mecanismo de rifteamento da porção oriental da margem norte brasileira, Revista Brasileira de Geociências. 17(2) (1987) 196-207.

[8] T.A. Hose, Selling the story of Britain's stone, Environmental Interpretation. 10(2) (1995) 1617.

[9] IBGE - Instituto Brasileiro de Geografia e Estatística. Censo Demográfico 2010 [Online]. Available: http://censo2010.ibge.gov.br/.

[10] E.F. Jardim de Sá, A Faixa Seridó (Província Borborema, NE do Brasil) eo seu significado geodinâmico na Cadeia Brasiliana/Pan-africana, PhD Thesis, Dept. Geology, Brasília Univ., Brasilia, Brazil, 1994.

[11] J.L. Laborel, Lês peuplements de madreporaires dês cotes tropicales du Brésil, Ann. Univ. d Abidjan, serie E, II fase. 2(3) (1969) 260 p. 
[12] A. Liccardo, V. Mantesso-Neto, G.F. Pierkarz, Geoturismo urbano: educação e cultura, Anuário do Instituto de Geociências- UFRJ. 35(1) (2012) 133-141.

[13] C. Lima et al., O Grupo Barreiras na Bacia Potiguar: relações entre o padrão de afloramento, estuturas pré-brasilianas e neotectonismo, in: 35 Brazilian Geology Congress - 1990, São Paulo, Brazil, 1990, pp. 607-620.

[14] K.L. Mansur, A.S. Silva, Society's response: Assessment of the Performance of the "Caminhos Geológicos" ("Geological Paths") Project, State of Rio de Janeiro, Brasil, Geoheritage. 3(1) (2011) 27-39.

[15] L. Martin et al., Texto explicativo para o mapa geológico do Quaternário Costeiro do Estado da Bahia. Escala 1:250.000. COM, SME, BA, 1982.

[16] M.A. Nóbrega et al., The use of apatite fission track thermochronology to constrain fault movements and sedimentary basin evolution in northeastern Brazil, Radiation Measurements. $39(6)$ (2005) 627-633.

[17] L.S. Pereira, H.M. Nogueira, Avaliação quantitativa do valor geoturístico do geopatrimónio caso do Litoral Sul Paraibano, Brasil, Cadernos de Geografia. 34 (2015) 55-65.

[18] L.S. Pereira, Potential Geomorphosites as locals of geotouristic interest: case of municipality of João Pessoa, Paraíba State (Brazilian NE), GeoJournal of Tourism and Geosites. 19 (2017) 7-21.

[19] L.S. Pereira, L.S. Cunha, Patrimônio Geomorfológico de João Pessoa, Paraíba: uma visão preliminar, in: 7 Congresso Nacional de Geomorfologia - 2015, Lisboa, 2015.

[20] L.S. Pereira, L.S. Lopes, Patrimônio geomorfológico do litoral sul do Estado da Paraíba e o geoturismo costeiro, in: 11 Simpósio Nacional de Geomorfologia - 2016, Maringá, 2016.

[21] S. Petri, Cretaceous paleogeographic maps of Brazil, Palaeogeography, Palaeoclimatology, Palaeoecology. 59 (1987) 117-168.

[22] G.F. Pierkarz, A. Liccardo, Programa Sítios Geológicos e Paleontológicos do Paraná- situação atual e tendências, in: 43 Brazilian Geology Congress - 2006, Aracaju, 2006.

[23] M.L. Rodrigues, A. Fonseca, A Valorização do geopatrimônio no desenvolvimento sustentável em áreas rurais. In Colóquio Ibérico em Estudos Rurais- Cultura, Inovação e Território - 2008, Coimbra, 2008.

[24] J.L. Rodriguez, Atlas Escolar da Paraíba, João Pessoa: Editora Grafset, 2002, pp. 37-38.

[25] J.L.S. Ross, Relevo brasileiro: uma nova proposta de classificação, Revista do Departamento de Geografia. 4 (1985) 25-39.

[26] D.F. Rossetti et al., Quaternary tectonics in a passive margin: Marajó Island, Northern Brazil, Journal of Quaternary Science. 23(2) (2008) 121-135.

[27] D.F. Rossetti; F.H. Bezerra; J.M.L. Dominguez, Late Oligocene-Miocene transgressions along the equatorial and eastern margins of Brazil, Earth-Science Reviews. 123 (2013) 87112.

[28] K. Suguio, L. Martin, Quaternary marine formations of the State of São Paulo and Southern Rio de Janeiro, in: International Symposium on Coastal Evolution in the Quaternary - 1978, São Paulo, 1978. 